of information from it». URL: https://zakon.rada.gov.ua/laws/show/328-2019\%D0\%BF (accessed: 11.03.2020).

7. Order of the Ministry of Economic Development, Trade and Agriculture of Ukraine dated December 13, 2019 № 677 « Classifier of diseases and health problems 025: 2019». URL: https://moz.gov.ua/dokumenti_(accessed: 11.03. 2020).

8. Ukrainian Cabinet of Ministers Resolution dated March 03, 2020 № 159 «Peculiarities of maintaining an electronic register of incapacitation lists to ensure informational interaction of eHealth with the electronic register of incapacitation lists». URL: $\quad$ https://www.kmu.gov.ua/npas/pro-osoblivosti-vedennya-elektronno-a159 (accessed: 11.03.2020).

9. The decision of the Oktyabrsk district court of the city. Dnipro of February 14, 2020 № 201/2923/19. URL: http://www.reyestr.court.gov.ua/Review/87587340 (accessed: 11.03.2020).

\title{
THE CURRENT STATE OF THE MEDICAL CRIME IN UKRAINE
}

\section{Kateryna Plutytska ${ }^{1}$}

DOI: https://doi.org/10.30525/978-9934-588-39-6-43

One of the priority activities of the government is to ensure an adequate standard of living and health of the population, including by maintaining and / or implementing effective legal and social mechanisms. Health care authorities play a leading role in ensuring a decent level of public health and in providing quality health care. However, there are numerous problems in the activities of these bodies, which are becoming more and more relevant over time. First of all, they include, the inadequate quality of medical care providing, the improper treatment of the professional duties, the abuse of the rank, the illegal experimentation on a human being, the illegal trafficking of the counterfeit medicinal products, etc. Further, the euthanasia still is the moot point. At the same time, according to the Art. 115 «Murder» of the Criminal Code of Ukraine euthanasia is a crime and entails criminal liability.

Now, the Criminal Code of Ukraine provides criminal liability for a number of crimes committed in the medical sphere, the main object of which is the life and health of man, namely: art. 131 «Professional misconduct causing infection of a person with HIV or any other incurable contagious disease», art. 132 «Disclosure of information on medical examination for HIV or any other incurable contagious disease», art. 134 «Illegal abortion or sterilization», art. 138 «Illegal medical practice»; article 139 «Failure of a

\footnotetext{
${ }^{1}$ Zaporizhzhia National University, Ukraine
} 
member of medical profession to provide help to a patient»; art. 140 «Improper performance of professional duty by a member of medical or pharmaceutical profession»; art. 141 «Violation of Rights of a Patient»; art. 142 «Illegal experimentation on a human being», art. 143 «Violation of procedures prescribed by law of transplantation of the anatomic human's materials»; art. 144 «Forcible donation of blood»; art. 145 «Unlawful disclosure of confidential medical information».

Thus, according to the General Reports about Crime in Ukraine in 2013-2019 of the Prosecutor General's Office of Ukraine, 4750 criminal offenses were considered, the responsibility for which is provided by the above articles of the Criminal Code of Ukraine $[1 ; 2 ; 3 ; 4 ; 5 ; 6 ; 7 ; 8 ; 9]$. The structure of crimes against human's life and health, which are committed in the medical sphere, consists of:

1) improper performance of professional duty by a member of medical or pharmaceutical profession (art. 140 of the Criminal Code of Ukraine) - 91,2\%;

2) failure of a member of medical profession to provide help to a patient (art. 139 of the Criminal Code of Ukraine) - 5,9\%;

3) illegal medical practice (art. 138 of the Criminal Code of Ukraine) - 0,8\%;

4) unlawful disclosure of confidential medical information (art. 145 of the Criminal Code of Ukraine) - 0,7\%;

5) violation of procedures prescribed by law of transplantation of the anatomic human's materials (art. 143 of the Criminal Code of Ukraine) - by 0,5\%;

6) illegal abortion or sterilization (art. 134 of the Criminal Code of Ukraine) - 0,4\%;

7) professional misconduct causing infection of a person with HIV or any other incurable contagious disease (art. 131 of the Criminal Code of Ukraine) $-0,3 \%$;

8) disclosure of information on medical examination for HIV or any other incurable contagious disease (art. 132 of the Criminal Code of Ukraine) - 0,1\%;

9) violation of Rights of a Patient (art. 141 of the Criminal Code of Ukraine) - 0,1\%;

10) forcible donation of blood (art. 144 of the Criminal Code of Ukraine) $0,02 \%$.

Accordingly, none illegal experimentation on a human being (art. 142 of the Criminal Code of Ukraine) was considered. In total, during the reporting period, investigated crimes accounted for about $1,4 \%$ of all crimes against human's life and health.

The analysis of time series showed that the number of crimes against human's life and health in the medical field is projected to increase by an average of 4 crimes per year over the next three years. 
But these figures should not be misleading, as the registration of such crimes is rather low and official statistics do not fully reflect the true state of affairs. In addition, the process of proving criminal activity in this area is very complex and criminal proceedings are still pending at the pre-trial stage (here we mean that the proceedings are either closed or remain unsuccessful). Thus, in the period from 2013 to 2019, only in $38(0.8 \%)$ of the criminal cases a suspect was identified; $31(0,7 \%)$ criminal cases were sent to court with an indictment; 2 criminal cases were sent to court with a motion for release from criminal responsibility.

Also, a large number of crimes remain undisclosed, allowing healthcare workers to be convinced of their impunity. According to experts, the level of latency of this group of crimes is high and the real level of these crimes far exceeds the official statistical indicators [8, p. 112]. There are several reasons for this, in our opinion.

Firstly, patients who become victims of these crimes do not inform law enforcement agencies about the fact of committing a criminal offense, because they don't believe that health care workers will be criminally persecuted.

Secondly, some health care managers do not respond properly to the offenses of their subordinates, as they do not want to damage the reputation of their institution.

Thirdly, as noted by Varigin O. and Chervonnykh E., a significant number of health care workers are experiencing professional and social-negative personality transformation. In addition, according to researchers from 400 respondents, only $16 \%$ were willing to testify against their colleague in court [9, p. 262], indicating the promotion of the phenomenon of «corporate solidarity» to the latentization of crimes against human's life and health that are committed in the medical field.

Thus, in order to create an effective mechanism for preventing these crimes, first of all, it is necessary to develop a set of general social measures aimed at overcoming high level of latency and to improve the ways and methods of investigating such crimes. The implementation of this trend will contribute not only to the reduction of crime rates, but also to the improvement of the quality of medical care, which today leaves much to be desired.

\section{References:}

1. Prosecutor General's Office of Ukraine (2013). Jedynyj zvit pro kryminaljni pravoporushennja za sichenj-ghrudenj 2013 [General Reports about Crime in JanuaryDecember 2013]. Retrieved from: https:/old.gp.gov.ua/ua/stst2011.html?dir_id= 110381\&libid=100820 (accessed 11 March 2020).

2. Prosecutor General's Office of Ukraine (2014). Jedynyj zvit pro kryminaljni pravoporushennja za sichenj-ghrudenj 2014 [General Reports about Crime in January- 
December 2014]. Retrieved from: https://old.gp.gov.ua/ua/stst2011.html?dir_id= 111482\&libid=100820 (accessed 11 March 2020).

3. Prosecutor General's Office of Ukraine (2015). Jedynyj zvit pro kryminaljni pravoporushennja za sichenj-ghrudenj 2015 [General Reports about Crime in JanuaryDecember 2015]. Retrieved from: https://old.gp.gov.ua/ua/stst2011.html?dir_id= 111482\&libid=100820\# (accessed 11 March 2020).

4. Prosecutor General's Office of Ukraine (2016). Jedynyj zvit pro kryminaljni pravoporushennja za sichenj-ghrudenj 2016 [General Reports about Crime in JanuaryDecember 2016]. Retrieved from: https://old.gp.gov.ua/ua/stst2011.html?dir_id= 111482\&libid=100820\# (accessed 11 March 2020).

5. Prosecutor General's Office of Ukraine (2017). Jedynyj zvit pro kryminaljni pravoporushennja za sichenj-ghrudenj 2017 [General Reports about Crime in JanuaryDecember 2017]. Retrieved from: https://old.gp.gov.ua/ua/stst2011.html?dir_id= 111482\&libid=100820\# (accessed 11 March 2020).

6. Prosecutor General's Office of Ukraine (2018). Jedynyj zvit pro kryminaljni pravoporushennja za sichenj-ghrudenj 2018 [General Reports about Crime in JanuaryDecember 2018]. Retrieved from: https://old.gp.gov.ua/ua/stst2011.html?dir_id= 111482\&libid=100820\# (accessed 11 March 2020).

7. Prosecutor General's Office of Ukraine (2019). Jedynyj zvit pro kryminaljni pravoporushennja za sichenj-ghrudenj 2019 [General Reports about Crime in JanuaryDecember 2019]. Retrieved from: https://old.gp.gov.ua/ua/stst2011.html?dir_id= 111482\&libid=100820\# (accessed 11 March 2020).

8. Tsymbaliuk, V. (2014). Kryminaljna vidpovidaljnistj medychnykh pracivnykiv za zlochyny proty zhyttja ta zdorov'ja osoby: naprjamky reformuvannja zakonodavstva [Criminal responsibility of medical personnel for crimes against life and health: law reform directions]. History and Law Journal, no. 2(4), pp. 111-115.

9. Varygin, A. N., \& Chervonnykh, E. V. (2008). Prestupnost' rabotnikov sfery zdravookhraneniya i ee tendentsii [Crimes of the health care workers and its tendency]. Gaps in Russianlegisllation, no. 2, pp. 260-262. 